\title{
MALAYSIAN B5 IMPLEMENTATION AND ITS QUALITY
}

YUNG CHEE LIANG*; SOH KHEANG LOH *; LIM WENG SOON* and CHOO YUEN MAY*

\begin{abstract}
A quality survey of 80 samples of diesel fuels (B5) from 80 retail stations throughout Peninsular Malaysia was performed. The biodiesel contents in these B5 samples were in the range of $4.61 \mathrm{vol}$. $\%$ to $5.33 \mathrm{vol} . \%$. The water contents of the samples were $<200 \mathrm{mg} \mathrm{kg}^{-1}$, meeting the stringent water requirements recommended by the car manufacturers. In addition, all the samples exhibited superior lubricity as indicated by a much shorter wear scar diameter compared to neat diesel. More importantly, 98\% of the samples passed the oxidation stability test (PetroOXY) with an induction period of $>65 \mathrm{~min}$. Overall, the B5 diesel fuel sold was in full compliance with the Malaysian diesel fuel standard specification.
\end{abstract}

Keywords: diesel fuel, biodiesel, B5, quality survey, retail stations.

Date received: 20 May 2016; Sent for revision: 2 June 2016; Received in final form: 5 August 2016; Accepted: 6 August 2016.

\section{INTRODUCTION}

Biodiesel, chemically known as fatty acid methyl ester (FAME), has been successfully produced, evaluated and identified as an important alternative fuel (Ali et al., 1995; Chang et al., 1996; Choo et al., 1995; 1997; Clark et al., 1984; Cvengros et al., 1999; Mittelbach and Enzelsberger, 1999). Biodiesel can be produced from various oils and fats in particular palm oil in the South-east Asia region (Choo et al., 1995; 1997). Diesel fuel blended with biodiesel at different allowable percentages have been implemented worldwide either on a voluntary or mandatory basis for the past few years, including Malaysia (Chong, 2013; Gonzalez, 2014; Vora, 2013).

The B5, B10, B20 and B5-B20 biodiesel blends were sold voluntarily at retail stations in Michigan, USA besides the neat diesel and neat ultra-low sulphur diesel (ULSD) (Tang et al., 2008). The BX is denoted as blend of $\mathrm{X}$ vol.\% biodiesel (fatty acid methyl ester) with $(100-X)$ vol.\% petroleum diesel.

\footnotetext{
Malaysian Palm Oil Board

6 Persiaran Institusi, Bandar Baru Bangi, 43000 Kajang

Selangor, Malaysia.

E-mail: clyung@mpob.gov.my
}

The biodiesel blends sold were of acceptable quality for parameters such as total acid number, derived cetane number (DCN), kinematic viscosity and cold flow properties. However, $45 \%$ of the samples did not meet the minimum $6 \mathrm{hr}$ of the Rancimat induction period (IP). The diesel fuel sold at the same location two years later still demonstrated that almost half of the samples did not comply with the limits for total acid number and oxidation stability as stipulated in the ASTM D 975 and/or D 7467 (Guzman et al., 2010). In addition, imprecise levels of the biodiesel blending ratio were detected in both surveys. There were significant variations between the reported and the actual biodiesel blending ratio, reflecting both the inappropriateness and the weakness of the splash blending procedures adopted. In a separate survey carried out nationwide in USA, during winter in 2009/2010, the stability of the B6-B20 biodiesel blends collected from retail stations was found to be problematic with a failure rate of $24 \%$ (Alleman et al., 2011).

In Malaysia, the B5 (blend of $5 \mathrm{vol} \%$ palm biodiesel with $95 \mathrm{vol} . \%$ petroleum diesel) programme was initiated in June 2011 at retail stations in the central region of Peninsular Malaysia, covering the areas of Putrajaya, Negeri Sembilan, Melaka, Kuala 
Lumpur and Selangor. Upon completion of the inline blending facilities at oil terminals at various locations, the B5 programme was further expanded to the southern region (Johor) in July 2013, the eastern region (Pahang, Terengganu and Kelantan) in February 2014 and the northern region (Perak, Pulau Pinang, Kedah and Perlis) in March 2014.

In order to assess the performance of the B5 implementation in Peninsular Malaysia, survey was conducted from January to August 2014 to check on the quality of 80 B5 samples sold at retail stations, and to ensure their compliance with the Malaysian Standard specification for diesel fuel MS123-1:2014 (DSM, 2014). The properties of the B5 samples were compared with those of neat diesel fuels sampled from retail stations in the northern region in October 2013 (before B5 implementation) so as to gauge their performance in diesel car engines.

\section{MATERIALS AND METHODS}

\section{Materials}

There are five oil companies operating retail businesses in Peninsular Malaysia. For each oil company, 16 diesel samples were obtained from 16 different retail stations at different locations as illustrated in Figure 1. The information on specific location, i.e. city, state, region and date of sampling are listed in Table 1. The names of the oil companies are not provided to remove bias in the analysis, interpretation and presentation of the results. These companies are denoted as OC-1 to OC-5.

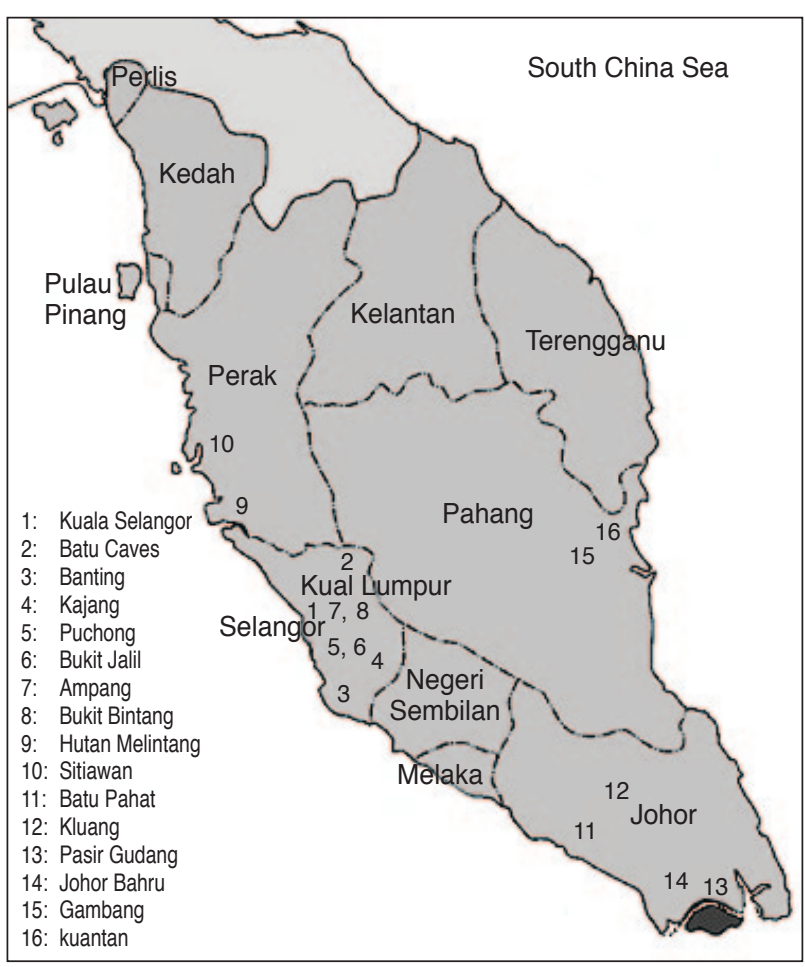

Figure 1. Location of the 80 retail stations for sampling of diesel fuel.

\section{Methods}

The diesel samples were analysed for their physico-chemical and fuel properties as follows:

Visual appearance inspection. Samples were visually inspected in a 1-litre transparent glass bottle in accordance to ASTM D4176 (ASTM International, 2014c). The presence of water droplets and particulates was recorded, if any.

Colour. The colour of the samples was measured according to ASTM D1500 (ASTM International, 2012d) using a Lovibond Tintotometer model AF 650 POC (Amesbury, UK).

Biodiesel content. The biodiesel content was measured using a Perkin Elmer model Spectrum 400 Fourier transform infrared (FTIR) spectrometer (UK) equipped with an attenuated total reflectance (ATR) sample cell according to ASTM D7371 (ASTM International, 2014e).

Water content. The water content was measured using a Metrohm 831 Karl Fischer Coulometer (Herisau, Switzerland) according to ISO 12937 (ISO, 2000).

Sediment by extraction. Sediment content was determined according to ASTM D473 (ASTM International, 2012c) using a Fisher Scientific extraction apparatus (USA).

Carbon residue on $10 \%$ bottoms. Carbon residue content was determined using an Alcor model MCRT-160 (USA) apparatus according to ASTM D189 (ASTM International, 2014a). Each sample was distilled using an automated distillation unit prior to being subjected to the carbon residue test.

Ash content. The samples were burnt to produce ash in a Thermo Concept furnace model KL 15/11 (Germany), and the ash content was calculated according to ASTM D482 (ASTM International, 2013b).

Cold flow properties. The cloud point $(\mathrm{CP})$, pour point (PP) and cold filter plugging point (CFPP) were determined according to the ASTM D5771 (ASTM International, 2012f), D5950 (ASTM International, 2014d) and EN 116 (IP, 1998), respectively. The measurements were performed using an ISL model CPP 97-2 cold flow properties analyser (Verson, France).

Flash point. The flash point was measured according to ASTM D93 (ASTM International, 2013a) using a Pensky-Martens closed cup automated flash point tester (Petrotest, Ludwid-Erhard-Ring, Germany). 
TABLE 1. DETAIL LOCATION AND DATE OF SAMPLING OF B5 DIESEL FUELS

\begin{tabular}{|c|c|c|c|c|c|}
\hline Sample ID & Oil company & City & State & Region & Date collected \\
\hline 1 & OC-1 & Kuala Selangor & Selangor & Central & 20-Jan-2014 \\
\hline 2 & OC-1 & Batu Caves & Selangor & Central & 20-Jan-2014 \\
\hline 3 & OC-2 & Kuala Selangor & Selangor & Central & 20-Jan-2014 \\
\hline 4 & OC-2 & Batu Caves & Selangor & Central & 20-Jan-2014 \\
\hline 5 & OC-3 & Kuala Selangor & Selangor & Central & 20-Jan-2014 \\
\hline 6 & OC-3 & Batu Caves & Selangor & Central & 20-Jan-2014 \\
\hline 7 & OC-4 & Kuala Selangor & Selangor & Central & 20-Jan-2014 \\
\hline 8 & OC-4 & Batu Caves & Selangor & Central & 20-Jan-2014 \\
\hline 9 & OC-5 & Kuala Selangor & Selangor & Central & 20-Jan-2014 \\
\hline 10 & OC-5 & Batu Caves & Selangor & Central & 20-Jan-2014 \\
\hline 11 & OC-1 & Banting & Selangor & Central & 27-Jan-2014 \\
\hline 12 & OC-1 & Kajang & Selangor & Central & 27-Jan-2014 \\
\hline 13 & OC-2 & Banting & Selangor & Central & 27-Jan-2014 \\
\hline 14 & OC-2 & Kajang & Selangor & Central & 27-Jan-2014 \\
\hline 15 & OC-3 & Banting & Selangor & Central & 27-Jan-2014 \\
\hline 16 & OC-3 & Kajang & Selangor & Central & 27-Jan-2014 \\
\hline 17 & OC-4 & Banting & Selangor & Central & 27-Jan-2014 \\
\hline 18 & OC-4 & Kajang & Selangor & Central & 27-Jan-2014 \\
\hline 19 & OC-5 & Banting & Selangor & Central & 27-Jan-2014 \\
\hline 20 & OC-5 & Kajang & Selangor & Central & 27-Jan-2014 \\
\hline 21 & OC-1 & Puchong & Selangor & Central & 11-Feb-2014 \\
\hline 22 & OC-1 & Bukit Jalil & Kuala Lumpur & Central & 11-Feb-2014 \\
\hline 23 & OC-2 & Puchong & Selangor & Central & 11-Feb-2014 \\
\hline 24 & OC-2 & Bukit Jalil & Kuala Lumpur & Central & 11-Feb-2014 \\
\hline 25 & OC-3 & Puchong & Selangor & Central & 11-Feb-2014 \\
\hline 26 & OC-3 & Bukit Jalil & Kuala Lumpur & Central & 11-Feb-2014 \\
\hline 27 & OC-4 & Puchong & Selangor & Central & 11-Feb-2014 \\
\hline 28 & OC-4 & Bukit Jalil & Kuala Lumpur & Central & 11-Feb-2014 \\
\hline 29 & OC-5 & Puchong & Selangor & Central & 11-Feb-2014 \\
\hline 30 & OC-5 & Bukit Jalil & Kuala Lumpur & Central & 11-Feb-2014 \\
\hline 31 & OC-1 & Ampang & Kuala Lumpur & Central & 27-Feb-2014 \\
\hline 32 & OC-1 & Bukit Bintang & Kuala Lumpur & Central & 27-Feb-2014 \\
\hline 33 & OC-2 & Ampang & Kuala Lumpur & Central & 27-Feb-2014 \\
\hline 34 & OC-2 & Bukit Bintang & Kuala Lumpur & Central & 27-Feb-2014 \\
\hline 35 & OC-3 & Ampang & Kuala Lumpur & Central & 27-Feb-2014 \\
\hline 36 & OC-3 & Bukit Bintang & Kuala Lumpur & Central & 27-Feb-2014 \\
\hline 37 & OC-4 & Ampang & Kuala Lumpur & Central & 27-Feb-2014 \\
\hline 38 & OC-4 & Bukit Bintang & Kuala Lumpur & Central & 27-Feb-2014 \\
\hline 39 & OC-5 & Ampang & Kuala Lumpur & Central & 27-Feb-2014 \\
\hline 40 & OC-5 & Bukit Bintang & Kuala Lumpur & Central & 27-Feb-2014 \\
\hline 41 & OC-1 & Hutan Melintang & Perak & Northern & 23-Apr-2014 \\
\hline 42 & OC-1 & Sitiawan & Perak & Northern & 23-Apr-2014 \\
\hline 43 & OC-2 & Hutan Melintang & Perak & Northern & 23-Apr-2014 \\
\hline 44 & OC-2 & Sitiawan & Perak & Northern & 23-Apr-2014 \\
\hline 45 & OC-3 & Hutan Melintang & Perak & Northern & 23-Apr-2014 \\
\hline 46 & OC-3 & Sitiawan & Perak & Northern & 23-Apr-2014 \\
\hline 47 & OC-4 & Hutan Melintang & Perak & Northern & 23-Apr-2014 \\
\hline 48 & OC-4 & Sitiawan & Perak & Northern & 23-Apr-2014 \\
\hline 49 & OC-5 & Hutan Melintang & Perak & Northern & 23-Apr-2014 \\
\hline 50 & OC-5 & Sitiawan & Perak & Northern & 23-Apr-2014 \\
\hline 51 & OC-1 & Batu Pahat & Johor & Southern & 29-Apr-2014 \\
\hline 52 & OC-1 & Kluang & Johor & Southern & 29-Apr-2014 \\
\hline 53 & OC-2 & Batu Pahat & Johor & Southern & 29-Apr-2014 \\
\hline 54 & OC-2 & Kluang & Johor & Southern & 29-Apr-2014 \\
\hline 55 & OC-3 & Batu Pahat & Johor & Southern & 29-Apr-2014 \\
\hline 56 & OC-3 & Kluang & Johor & Southern & 29-Apr-2014 \\
\hline 57 & OC-4 & Batu Pahat & Johor & Southern & 29-Apr-2014 \\
\hline 58 & OC-4 & Kluang & Johor & Southern & 29-Apr-2014 \\
\hline 59 & OC-5 & Batu Pahat & Johor & Southern & 29-Apr-2014 \\
\hline
\end{tabular}


TABLE 1. DETAIL LOCATION AND DATE OF SAMPLING OF B5 DIESEL FUELS (continued)

\begin{tabular}{|c|c|c|c|c|c|}
\hline Sample ID & Oil company & City & State & Region & Date collected \\
\hline 60 & OC-5 & Kluang & Johor & Southern & 29-Apr-2014 \\
\hline 61 & OC-1 & Pasir Gudang & Johor & Southern & 6-Aug-2014 \\
\hline 62 & OC-1 & Johor Bahru & Johor & Southern & 6-Aug-2014 \\
\hline 63 & OC-2 & Pasir Gudang & Johor & Southern & 6-Aug-2014 \\
\hline 64 & OC-2 & Johor Bahru & Johor & Southern & 6-Aug-2014 \\
\hline 65 & OC-3 & Pasir Gudang & Johor & Southern & 6-Aug-2014 \\
\hline 66 & OC-3 & Johor Bahru & Johor & Southern & 6-Aug-2014 \\
\hline 67 & OC-4 & Pasir Gudang & Johor & Southern & 6-Aug-2014 \\
\hline 68 & OC-4 & Johor Bahru & Johor & Southern & 6-Aug-2014 \\
\hline 69 & OC-5 & Pasir Gudang & Johor & Southern & 6-Aug-2014 \\
\hline 70 & OC-5 & Johor Bahru & Johor & Southern & 6-Aug-2014 \\
\hline 71 & OC-1 & Gambang & Pahang & Eastern & 16-Aug-2014 \\
\hline 72 & OC-1 & Kuantan & Pahang & Eastern & 16-Aug-2014 \\
\hline 73 & OC-2 & Gambang & Pahang & Eastern & 16-Aug-2014 \\
\hline 74 & OC-2 & Kuantan & Pahang & Eastern & 16-Aug-2014 \\
\hline 75 & OC-3 & Gambang & Pahang & Eastern & 16-Aug-2014 \\
\hline 76 & OC-3 & Kuantan & Pahang & Eastern & 16-Aug-2014 \\
\hline 77 & OC-4 & Gambang & Pahang & Eastern & 16-Aug-2014 \\
\hline 78 & OC -4 & Kuantan & Pahang & Eastern & 16-Aug-2014 \\
\hline 79 & OC -5 & Gambang & Pahang & Eastern & 16-Aug-2014 \\
\hline 80 & OC-5 & Kuantan & Pahang & Eastern & 16-Aug-2014 \\
\hline
\end{tabular}

Electrical conductivity. The electrical conductivity was measured using an Emcee digital conductivity meter model 1152-X1 (Venice, Italy) according to ASTM D2624 (ASTM International, 2009).

Kinematic viscosity at $40^{\circ} \mathrm{C}$. The kinematic viscosity was measured at $40^{\circ} \mathrm{C}$ according to ASTM D445 (ASTM International, 2014b) using a Herzog viscometer model HVM 472 (Lauda-Konigshofen, Germany).

Density at $15^{\circ} \mathrm{C}$. The density was measured according to ASTM D4052 (ASTM International, 2011b) using a Mettler-Toledo digital density meter model DE40 (Schwerzenbach, Switzerland) at $15^{\circ} \mathrm{C}$.

Physical distillation at $95 \%$ recovered volume, T95. The distillation profile was obtained using a PAC model Optidist automated distillation unit (Germany) according to ASTM D86 (ASTM International, 2012a).

Derived cetane number (DCN). The DCN was determined according to ASTM D6890 (ASTM International, 2013c) in an Ignition Quality Tester $\left(\mathrm{IQT}^{\mathrm{TM}}\right.$ ) (Advanced Engine Technology Ltd, Ontario, Canada).

Lubricity. The samples were subjected to a High Frequency Reciprocating Rig (PCS Instruments, London, UK) at $60^{\circ} \mathrm{C}$ according to ASTM D6079 (ASTM International, 2011c). The lubricity of each sample was characterised by measuring the wear scar diameter (WSD) produced on the upper specimen using a microscope. Short WSD generated indicates better lubricity of the fuel.

Sulphur content. The sulphur content was determined according to ASTM D5453 (ASTM International, 2012e) using a Mitsubishi Total Sulphur Analyser model TS-100 (Kanagawa, Japan).

Oxidation stability. The oxidation stability was determined via the IP. The IP was measured according to ASTM D7545 (ASTM International, 2013d) using PetroOXY (Petrotest, Ludwid-ErhardRing, Germany) at $140^{\circ} \mathrm{C}$ in an oxygen pressurised vessel.

Copper strip corrosion. Copper strip corrosion was performed for $3 \mathrm{hr}$ at $50^{\circ} \mathrm{C}$ according to ASTM D130 (ASTM International, 2012b), using a Petrotest DP bath (Ludwid-Erhard-Ring, Germany). The corrosion readings were reported based on a comparison of the copper strips against the standard.

Acid number. The acid number of the sample was determined according to ASTM D664 (ASTM International, 2011a) using a Metrohm 809 Titrando (Herisau, Switzerland).

\section{RESULTS AND DISCUSSION}

The physico-chemical and fuel properties of the B5 diesel fuels obtained from five oil companies are summarised in Table 2. Table 3 presents the properties of the neat diesel fuels obtained from the northern 


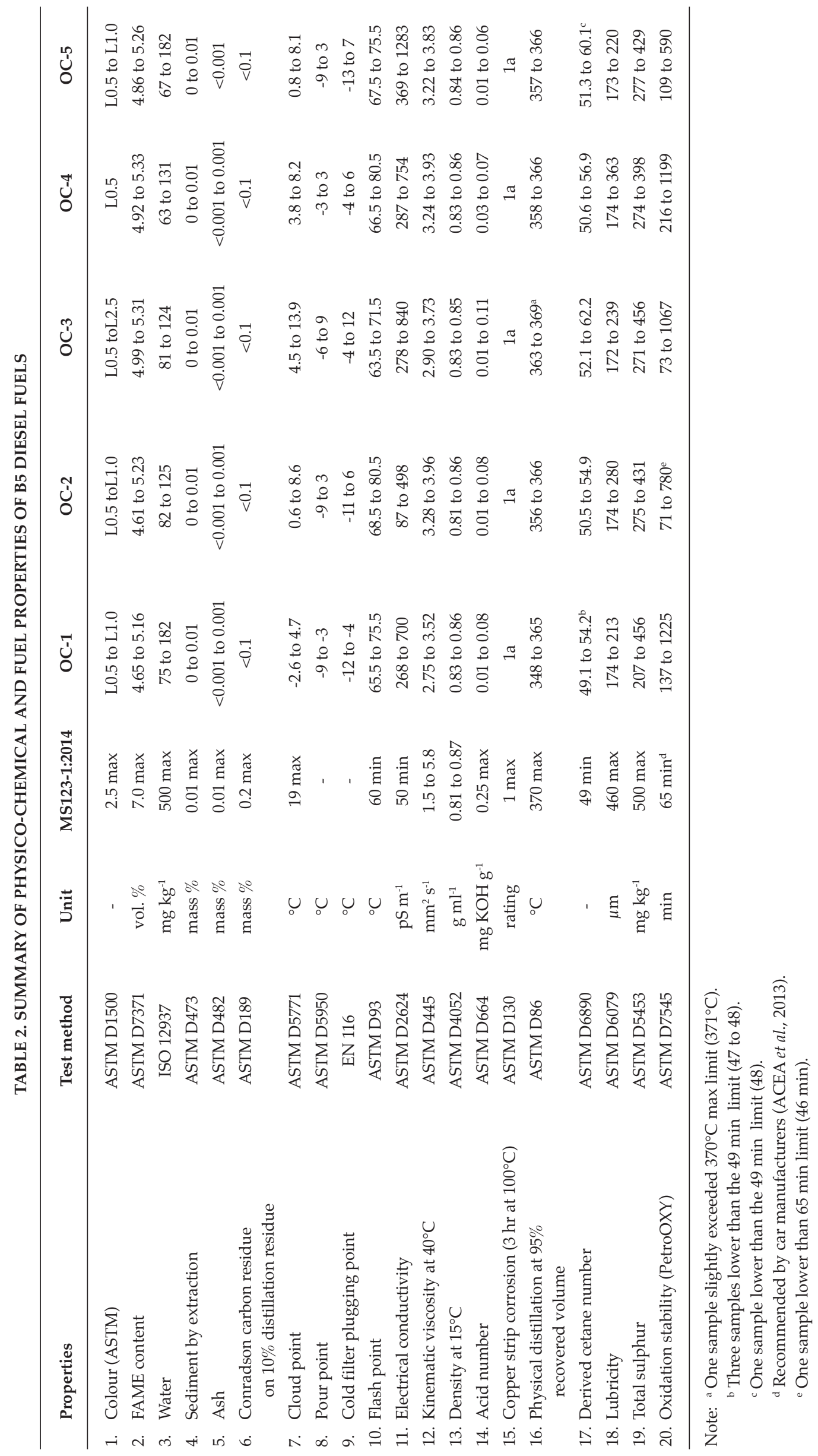




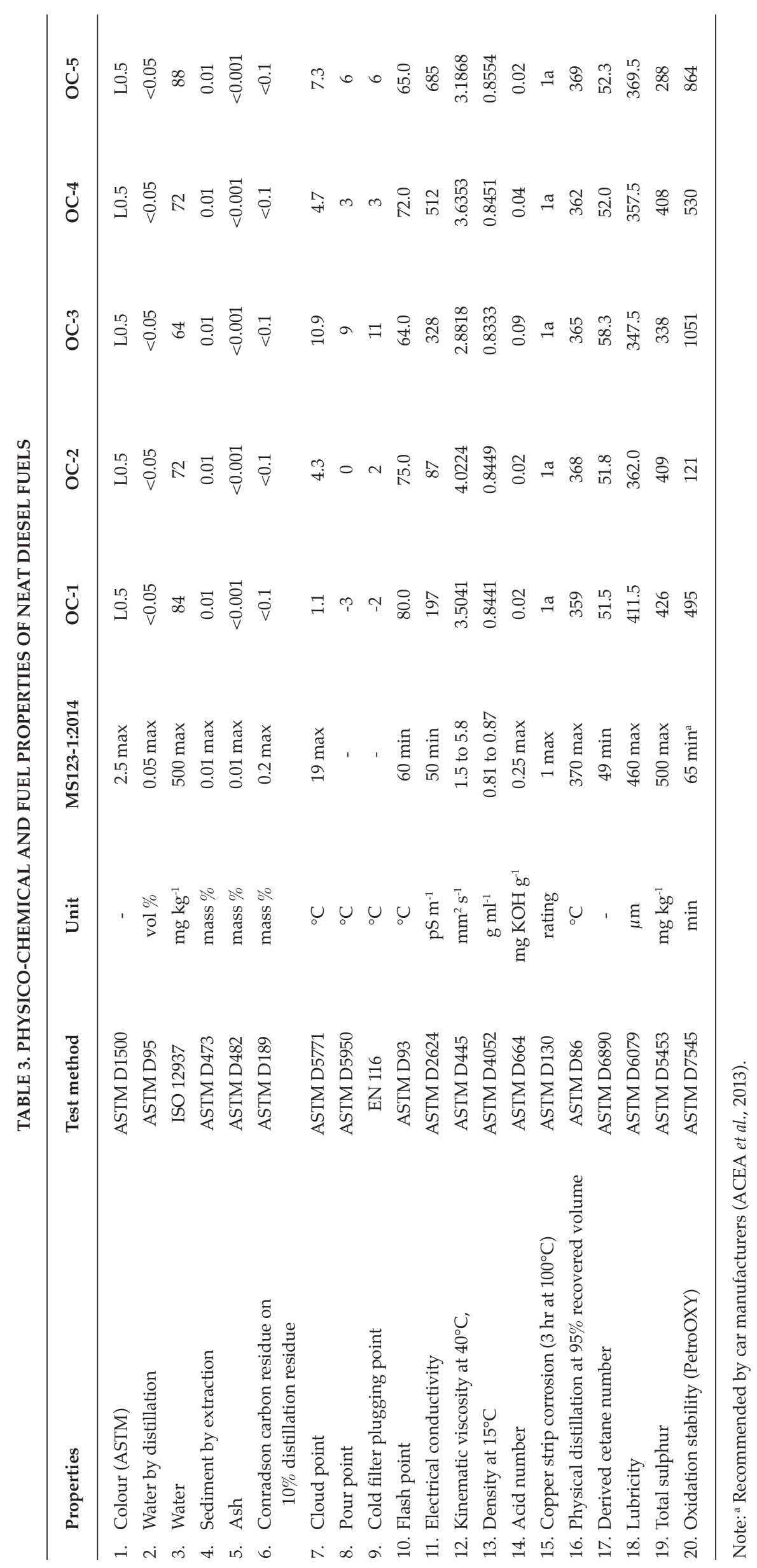


region of Peninsular Malaysia in October 2013, prior to the implementation of the B5 programme. These data served as the basis for comparison with the properties of the B5 diesel samples. The samples in the current study were tested only once to assess their compliance with the Malaysian Standard Specification for Diesel Fuel, MS123-1:2014. Reproducibility $(\mathrm{R})$ of the results of the test methods were indicated in the captions for figures.

All 80 B5 diesel samples passed the visual inspection. The samples were found clear and bright without the presence of water and/or particulates, thus indicating no possible contamination in the B5 diesel fuel. The colour of the B5 diesel sample was in the range of L0.5 to L1.5, except for one sample, which was slightly darker, and the result of L2.5 was reported. Overall, the appearance of all of the samples was acceptable and there were no signs of unusual contamination and fuel degradation.

Biodiesel was blended into diesel fuel via inline blending facilities installed at various oil terminals prior to distribution to the respective retail stations. The measured biodiesel content in B5 diesel fuels was in the range of $4.61 \mathrm{vol} . \%$ to $5.33 \mathrm{vol} . \%$. This indicated that the inline blending facilities were able to provide homogenous blending in accordance with the mandate set by the government, i.e. 5 vol. $\%$ biodiesel.

The water content of the B5 diesel fuels is shown in Figure 2. All the 80 B5 diesel samples were found to have water content well below 200 $\mathrm{mg} \mathrm{kg}{ }^{-1}$, meeting the stringent requirement of 0.05 vol.\% as stipulated in MS123-1:2014 (DSM, 2014) and the $200 \mathrm{mg} \mathrm{kg}^{-1}$ maximum limit requested by car manufacturers (ACEA et al., 2013). The sediment in all the 80 B5 diesel samples showed consistent readings which ranged from 0 to 0.01 mass $\%$; the lowest detectable limit as stipulated in ASTM D473. To provide more sensitive readings at parts per million levels, methods such as total contamination EN 12662 should be considered in the future study.

All the B5 diesel samples were in full compliance with the carbon residue and ash specifications, i.e. $<0.1$ mass $\%$ and $\leq 0.001$ mass $\%$, respectively. This indicated that all the B5 diesel fuels were free of any carbonaceous residues and thus indicating no formation of non-burnable deposits which may contribute to wear and tear in the fuel system, i.e. fuel injector, fuel pump and piston (ACEA et al., 2013; Westbrook and LeCren, 2009).

The CP, PP and CFPP are parameters determining the operational behaviour of a diesel fuel at the lowest possible temperature. In MS1231:2014, only CP was selected as a specification for the cold flow behaviour of diesel fuel. All of the B5 diesel samples complied with the $\mathrm{CP}$ requirement specified in MS123-1:2014, with 10 samples having $\mathrm{CP}$ values of $10^{\circ} \mathrm{C}$ to $15^{\circ} \mathrm{C}, 37$ samples in the range of $5^{\circ} \mathrm{C}$ to $10^{\circ} \mathrm{C}$, and the remaining 33 samples $<5^{\circ} \mathrm{C}$. The highest $\mathrm{CP}$ recorded i.e. $13.9^{\circ} \mathrm{C}$ was well below the upper limit set $\left(19^{\circ} \mathrm{C}\right)$, enabling $\mathrm{B} 5$ diesel fuel to be used all year round in hot climate like Malaysia. Figures 3 to 5 show the differences in the cold flow properties, i.e. CP, PP and CFPP for the diesel fuels supplied by all five oil companies. All of them exhibited similar cold flow behaviours; with fuel from OC-3 having a higher cold flow temperature while fuels from OC-2, OC- 4 and OC-5 at a moderate range, and $\mathrm{OC}-1$ at a lower range. Additionally, blending of 5 vol. $\%$ palm biodiesel into petroleum diesel hardly showed any changes on its cold flow properties. This was evidenced from the insignificant increment of the CP, PP and CFPP of the B5 diesel samples, despite palm biodiesel possessing much higher cold flow properties, i.e $15^{\circ} \mathrm{C}$ (Yung et al., 2006; 2013).

The flash points of all the B5 diesel fuels were in the range of $63.5^{\circ} \mathrm{C}$ to $80.5^{\circ} \mathrm{C}$, thus complying

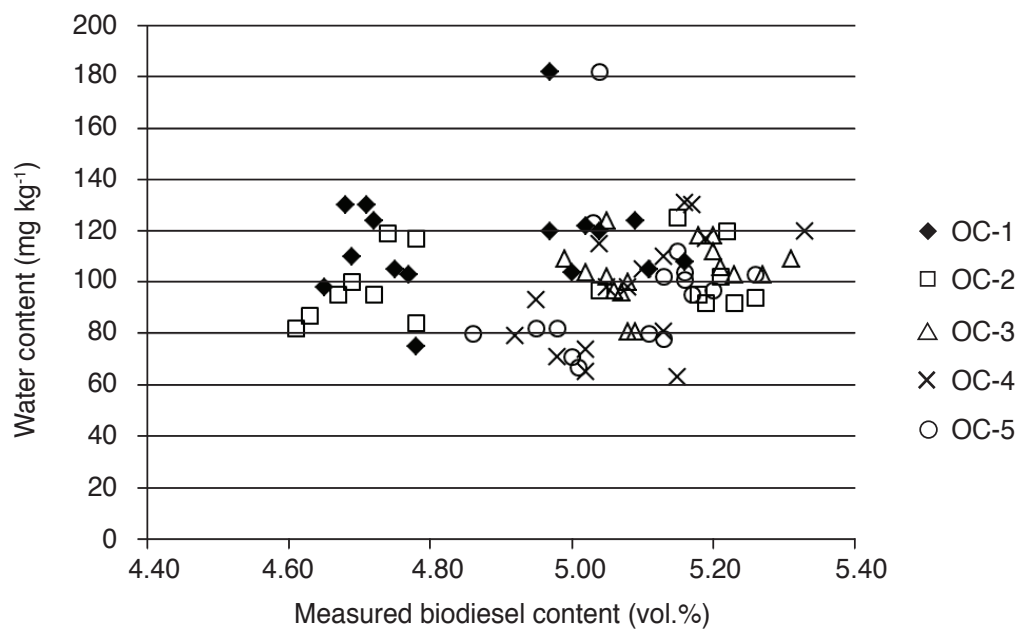

Figure 2. Plot of the water content vs. the measured biodiesel content of the diesel samples obtained from five oil companies. $R=0.0477(X+14.905)$ for biodiesel [fatty acid methyl ester (FAME)] content, $R=0.06877 \mathrm{X}^{\wedge} 0.5$ for water content. 


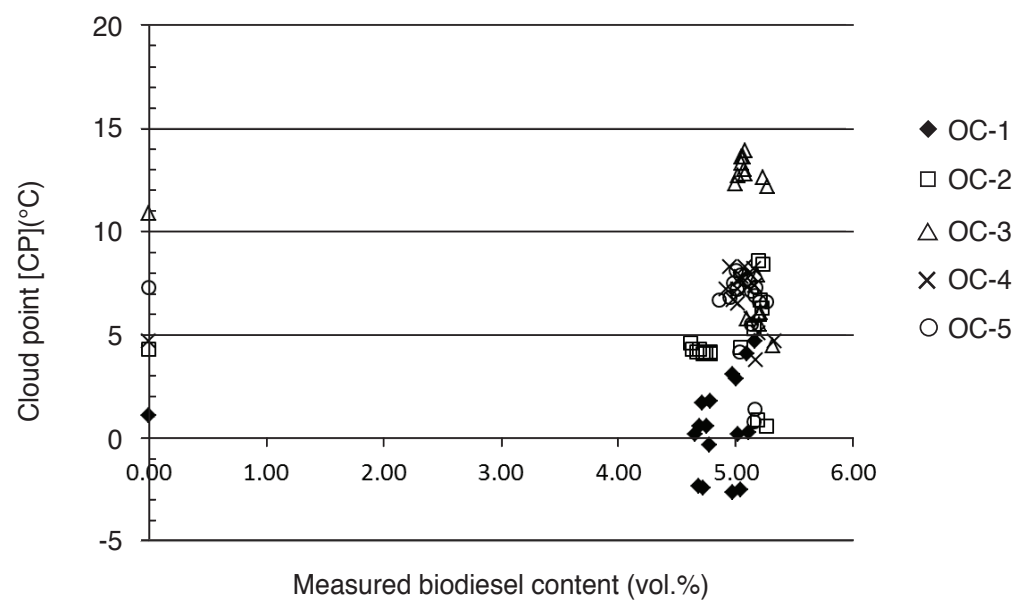

Figure 3. Cloud points vs. measured biodiesel content of diesel samples obtained from five oil companies. $R=0.0477(X+14.905)$ for biodiesel [fatty acid methyl ester (FAME)] content, $R=2.7^{\circ} \mathrm{C}$ for cloud point.

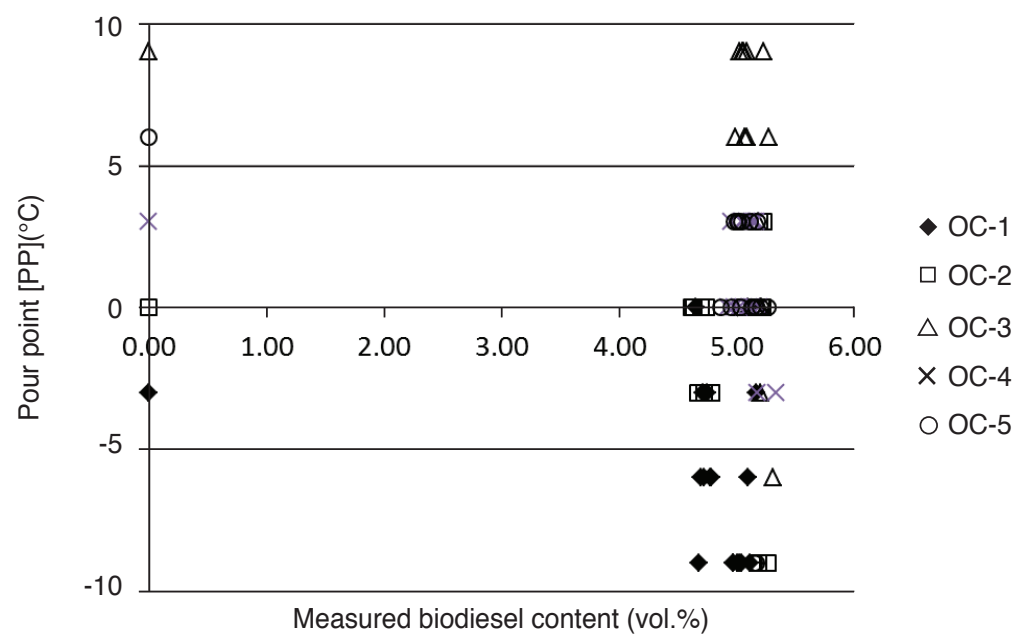

Figure 4. Plot of the pour point vs. the measured biodiesel content of the diesel samples obtained from five oil companies. $R=0.0477(X+14.905)$ for biodiesel [fatty acid methyl ester (FAME)] content, $R=6.1^{\circ} \mathrm{C}$ for pour point.

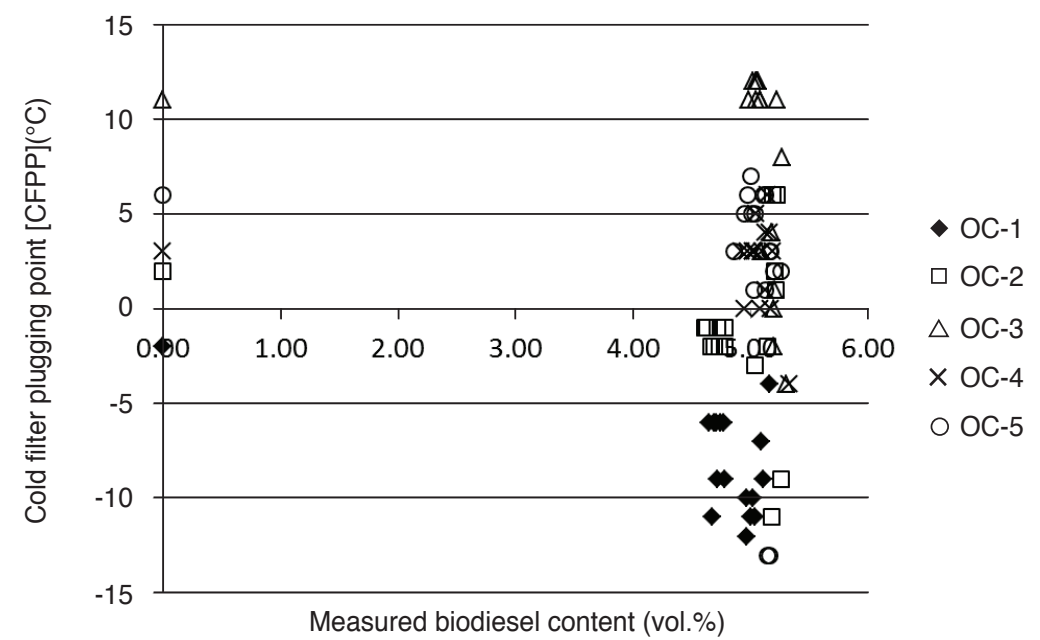

Figure 5. Plot of the CFPP vs. the measured biodiesel content of the diesel samples obtained from five oil companies. $R=0.0477(X+14.905)$ for biodiesel [fatty acid methyl ester (FAME)] content, $R=0.103(25-X)$ for cold filter plugging point. 
with the minimum requirement set for local diesel consumption, i.e. $60^{\circ} \mathrm{C}$. Similar to the cold flow properties, the blending of $5 \mathrm{vol} . \%$ of biodiesel into petroleum diesel showed insignificant effect, despite palm biodiesel exhibiting much higher flash point, i.e. $182^{\circ} \mathrm{C}$ (Yung et al., 2006; 2013). Nevertheless, this also indicated that the B5 diesel fuel is safe to be stored and transported throughout Malaysia for B5 implementation. This was further supported by the high conductivity of the B5 diesel fuels indicating rapid charges dissipation during pumping and filtration operations, thereby preventing the accumulation of charges and avoiding potential dangerous explosion in the storage tank.

The kinematic viscosity and density of all the B5 diesel samples were within the specified limits, i.e. in the ranges of 2.75 to $3.96 \mathrm{~mm}^{2} \mathrm{~s}^{-1}$ and 0.81 to 0.86 $\mathrm{g} \mathrm{ml}^{-1}$, respectively. The copper strip corrosion and the acid number serve as parameters that indirectly indicate the degradation of a fuel. All the B5 samples demonstrated class 1 a for the copper strip corrosion and acid number in the range of 0.01 to $0.11 \mathrm{mg}$ $\mathrm{KOH} \mathrm{g}{ }^{-1}$. As such, there was no degradation in the B5 diesel; all of them were well preserved during storage and transportation and thus, the was no formation of oxidised acidic compounds that could harm the engine components.

For distillation, only one out of 80 samples slightly exceeded the temperature limit at the $95 \%$ recovered volume (T95) i.e. $370^{\circ} \mathrm{C}$ vs. $371^{\circ} \mathrm{C}$; thus may have slight tendency to generate more tailpipe emission from the vehicles in use. In particular, higher NOx and particulate matter emission from heavy and light duty engines, respectively could be anticipated (ACEA et al., 2013).

In general, all the neat diesel and B5 diesel fuels met the minimum DCN limit of 49 except for four samples with slightly lower DCN value of 47 to 48 . The B5 diesel fuels in the present study had a slightly improved DCN compared to those of neat diesel fuels. The DCN of neat diesel and B5 diesel fuels from OC-3 was the highest, probably due to the higher concentration of straight chain paraffinic hydrocarbons in the diesel component which had the tendency to ignite more readily under compression compared to those of branched chain and aromatic hydrocarbons in the rest of the blended fuels (Westbrook and LeCren, 2009). However, the presence of higher straight chain paraffinic hydrocarbons also had a higher tendency to crystallise at higher temperature thus affecting the cold flow behaviours of a fuel such as the one observed from OC-3 (Figures 6 and 7).

The lubricity of a fuel is characterised by measuring the WSD produced on the steel ball reciprocated on a steel disk under specific pressure and temperature in the presence of a thin layer of fuel. A shorter WSD represents a higher lubricity property. Figure 8 shows that the WSD of the B5 diesel samples were much shorter, thus better lubricity than those for the neat diesel samples. Generally, blending 5 vol.\% of palm biodiesel into the neat diesel had significantly enhanced its lubricity from a maximum WSD of $460 \mu \mathrm{m}$ to $<300 \mu \mathrm{m}$.

Palm biodiesel is typically low in sulphur content (Yung et al., 2013). Theoretically, blending 5 vol.\% of palm biodiesel into neat diesel will relatively lower its sulphur content by approximately $5 \%$. The sulphur content of the B5 diesel samples in the present study ranged from 210 to $456 \mathrm{mg} \mathrm{kg}^{-1}$, thus complying with the limit $\left(500 \mathrm{mg} \mathrm{kg}^{-1}\right)$ allowable in Malaysia. In fact, Malaysia has planned to further reduce the sulphur content to $10 \mathrm{mg} \mathrm{kg}^{-1}$ in the near future. This can be done via hydrotreating process in petroleum refineries; with the shortcoming that this will result in poorer lubricity of the fuel produced. However, this negative attribute can be overcome by the national biodiesel programme. The presence of palm biodiesel, even at a small quantity, i.e. $5 \mathrm{vol} . \%$, is able to restore the lubricity of the fuel; thus the addition of an expensive lubricity additive is not required.

Oxidation stability is a concern when biodiesel is introduced into a diesel fuel. Biodiesel is more susceptible to oxidation, especially in the presence of water and air. However, palm biodiesel is also known to have a superior oxidation stability among all of the biodiesels produced from oils and fats (Yung et al., 2006; 2013). The present study employed PetroOXY (ASTM D7545) as a means to suitably accelerate oxidation of the B5 diesel fuels. As indicated in Tables 2 and 3, of all the 80 B5 diesel samples, only one sample did not pass the OEM recommended minimum IP of $65 \mathrm{~min}$, the rest with IP $>65$ to 1206 min (Figure 9). The less stable B5 samples (IP between 65-100 min) and their neat counterparts were mainly from OC-2 at central region. Since there was no sign of any increase in the acid number and water content, and all passed the copper strip corrosion test, the less stability of the B5 samples was probably inherited from the neat diesel component; thus eliminating the possible cause by long-term storage and/or fuel degradation in the underground fuel tanks.

\section{CONCLUSION}

The B5 diesel fuels obtained from 80 retail stations contained 4.61 vol. $\%$ to 5.33 vol. $\%$ palm biodiesel with very promising quality. This showed great commitment by the oil companies to support the national B5 programme. All the samples were in full compliance with the parameters stipulated in the local diesel specification, except for one slightly exceeded the T95 temperature and oxidation IP, and few others with slightly lower DCN than the locally allowed standards. More importantly, all the 


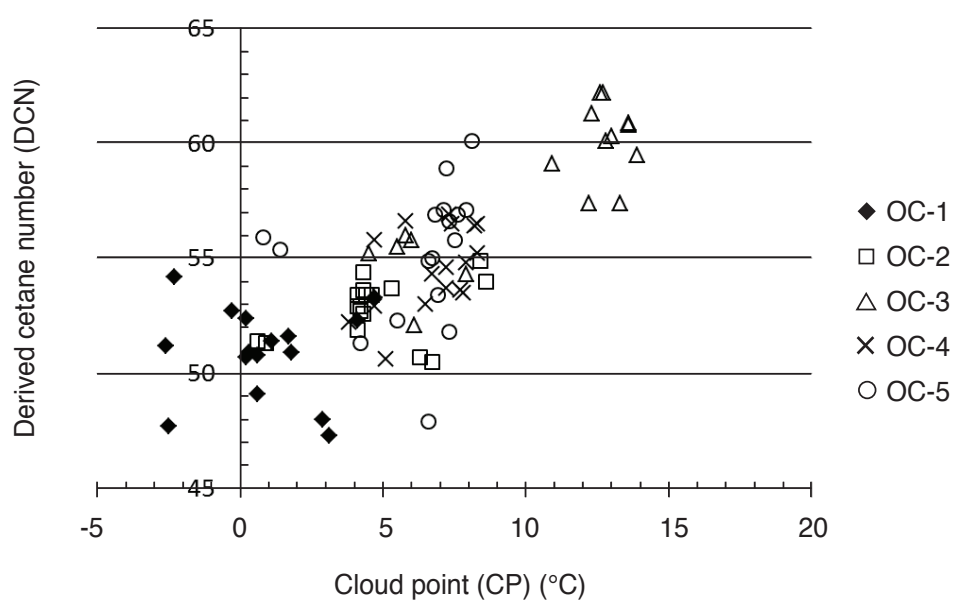

Figure 6. Plot of the derived cetane number vs. the cloud point of the diesel samples obtained from five oil companies. $R=0.0385(X+18)$ for $D C N, R=2.7^{\circ} \mathrm{C}$ for cloud point.

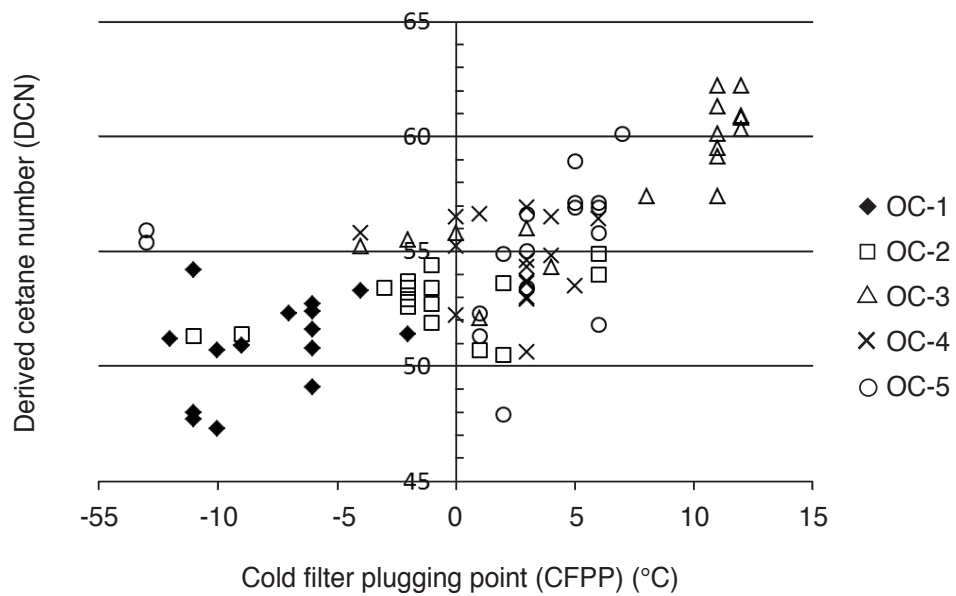

Figure 7. Plot of the derived cetane number vs. the cold filter plugging point (CFPP) of the diesel samples obtained from five oil companies. $R=0.0385(X+18)$ for $D C N, R=0.103(25-X)$ for $C F P P$.

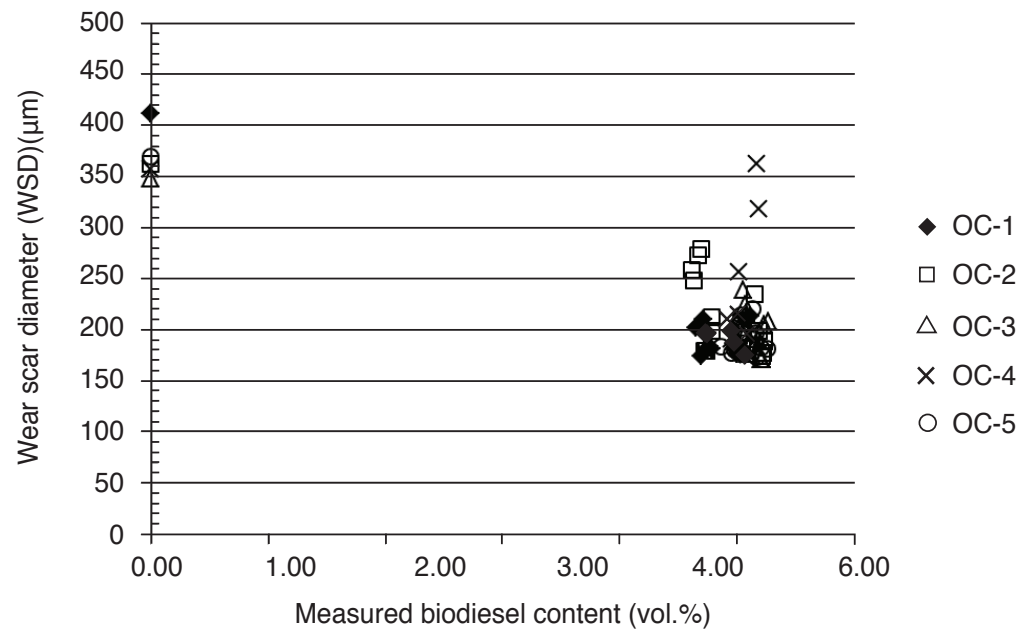

Figure 8. Plot of the wear scar diameter (WSD) value vs. the measured biodiesel content of the diesel samples obtained from five oil companies. $R=0.0477(X+14.905)$ for biodiesel [fatty acid methyl ester (FAME)] content, $R=80 \mu \mathrm{m}$ for lubricity. 


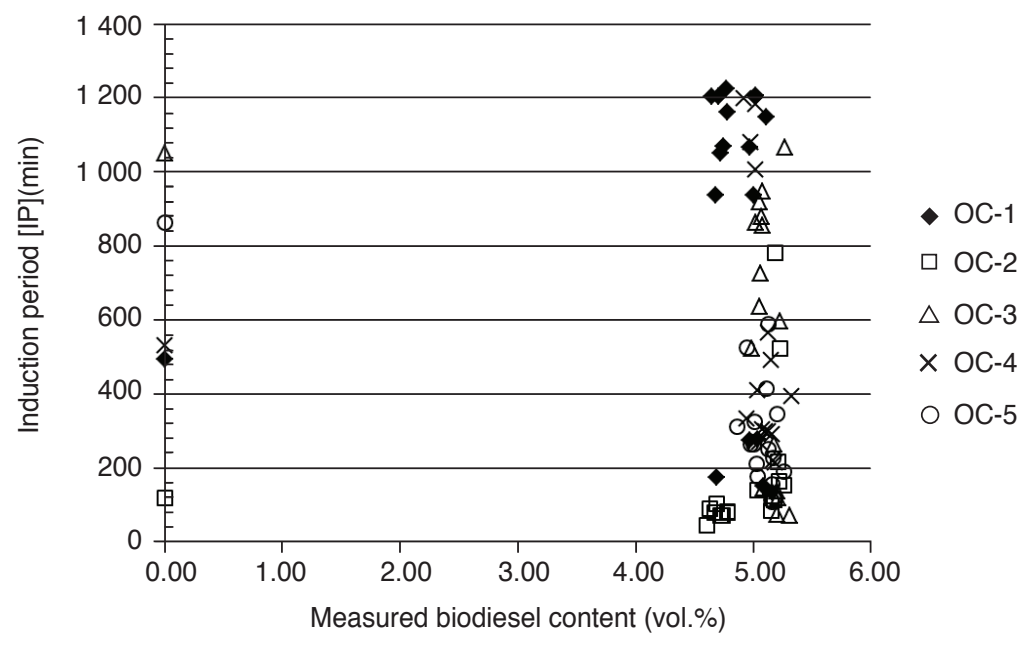

Figure 9. Plot of the induction period (IP) values vs. the measured biodiesel content of the diesel samples obtained from five oil companies. $R=0.0477(X+14.905)$ for biodiesel [fatty acid methyl ester (FAME)] content, $R=0.0863 X+1.3772$ for oxidation stability.

samples complied with the stringent requirement of a low water content $\left(<200 \mathrm{mg} \mathrm{kg}^{-1}\right)$ and demonstrated superior oxidative stability. In general, the 5 vol.\% palm biodiesel blended had not just maintained the fuel quality but improved significantly some of the fuel properties, e.g. the ignition quality and lubricity.

\section{ACKNOWLEDGEMENT}

The authors thank MPOB for the financial support provided for the study. Thanks are also due to the staff of the Energy and Environment Unit, MPOB for their technical assistance.

\section{REFERENCES}

ACEA; ALLIANCE; EMA and JAMA (2013). Worldwide Fuel Charter. $5^{\text {th }}$ edition. http://www. acea.be/ uploads / publications / Worldwide_Fuel_ Charter_5ed_2013.pdf

ALI, Y; HANNA, M A and CUPPETT, S L (1995). Fuel properties of tallow and soybean oil esters. $J$. Amer. Oil Chem. Soc., 72: 1557-1564.

ALLEMAN, T L; FOUTS, L and MCCORMICK, R L (2011). Quality analysis of wintertime B6-B20 biodiesel blend samples collected in the United States. Fuel Processing Tech., 92: 1297-1304.

ASTM INTERNATIONAL (2009). ASTM D262409 Standard Test Methods for Electrical Conductivity of Aviation and Distillate Fuels. ASTM International, Philadelphia.

ASTM INTERNATIONAL (2011a). ASTM D66411a Standard Test Method for Acid Number of
Petroleum Products by Potentiometric Titration. ASTM International, Philadelphia.

ASTM INTERNATIONAL (2011b). ASTM D405211a Standard Test Method for Density, Relative Density, and API Gravity of Liquids by Digital Density Meter. ASTM International, Philadelphia.

ASTM INTERNATIONAL (2011c). ASTM D6079-11 Standard Test Method for Evaluating Lubricity of Diesel Fuels by High-Frequency Reciprocating Rig (HFRR). ASTM International, Philadelphia.

ASTM INTERNATIONAL (2012a). ASTM D8612 Standard Test Method for Distillation of Petroleum Products at Atmospheric Pressure. ASTM International, Philadelphia.

ASTM INTERNATIONAL (2012b). ASTM D13012 Standard Test Method for Corrosiveness to Copper from Petroleum Products by Copper Strip Test. ASTM International, Philadelphia.

ASTM INTERNATIONAL (2012c). ASTM D473-07 Standard Test Method for Sediment in Crude Oils and Fuel Oils by Extraction Method. ASTM International, Philadelphia.

ASTM INTERNATIONAL (2012d). ASTM D150012 Standard Test Method for ASTM Color of Petroleum Products (ASTM color scale). ASTM International, Philadelphia.

ASTM INTERNATIONAL (2012e). ASTM D545312 Standard Test Method for Determination of Sulfur in Light Hydrocarbons, Spark Ignition Engine Fuel, Diesel Engine Fuel, and Engine Oil by Ultraviolet Fluorescence. ASTM International, Philadelphia. 
ASTM INTERNATIONAL (2012f). ASTM D577112 Standard Test Method for Cloud Point of Petroleum Products (optical detection stepped cooling method). ASTM International, Philadelphia.

ASTM INTERNATIONAL (2013a). ASTM D93$13 \varepsilon 1$ Standard Test Methods for Flash Point by PenskyMartens Closed Cup Tester. ASTM International, Philadelphia.

ASTM INTERNATIONAL (2013b). ASTM D482-13 Standard Test Method for Ash from Petroleum Products. ASTM International, Philadelphia.

ASTM INTERNATIONAL (2013c). ASTM D689013be1 Standard Test Method for Determination of Ignition Delay and Derived Cetane Number (DCN) of Diesel Fuel Oils by Combustion in a Constant Volume Chamber. ASTM International, Philadelphia.

ASTM INTERNATIONAL (2013d). ASTM D7545-13 Standard Test Method for Oxidation Stability of Middle Distillate Fuels-rapid Small Scale Oxidation Tester (RSSOT). ASTM International, Philadelphia.

ASTM INTERNATIONAL (2014a). ASTM D18906 Standard Test Method for Conradson Carbon Residue of Petroleum Products. ASTM International, Philadelphia.

ASTM INTERNATIONAL (2014b). ASTM D44514a Standard Test Method for Kinematic Viscosity of Transparent and Opaque Liquids (and calculation of dynamic viscosity). ASTM International, Philadelphia.

ASTM INTERNATIONAL (2014c). ASTM D4176-04 Standard Test Method for Free Water and Particulate Contamination in Distillate Fuels (visual inspection procedures). ASTM International, Philadelphia.

ASTM INTERNATIONAL (2014d). ASTM D595014 Standard Test Method for Pour Point of Petroleum Products (automatic tilt method). ASTM International, Philadelphia.

ASTM INTERNATIONAL (2014e). ASTM D737114 Standard Test Method for Determination of Biodiesel (fatty acid methyl esters) Content in Diesel Fuel Oil Using Mid Infrared Spectroscopy (FTIR-ATR-PLS method). ASTM International, Philadelphia.

CHANG, D Y Z; VAN GERPEN, J H; LEE, I and JOHNSON, L A (1996). Fuel properties and emissions of soybean oil esters as diesel fuel. J. Amer. Oil Chem. Soc., 73: 1549-1555.

CHONG, K (2013). Asia Pacific: biodiesel blending has an edge over ethanol in expansion plans for 2014. Hart Energy Special Report (4 November).
CHOO, Y M; MA, A N and BASIRON, Y (1995). Preparation and evaluation of palm oil methyl esters as diesel substitute. Elaeis Special Issue: 5-25.

CHOO, Y M; MA, A N and ONG, A S H (1997). Biofuels. Lipids: Industrial Applications and Technology (Gunstone, F D and Padley, F B eds.). New York: Marcell Dekker Inc, p. 771-785.

CLARK, S J; WAGNER, L; SCHROCK, $M$ and PIENNAAR, P G (1984). Methyl and ethyl soybean esters as renewable fuels for diesel engines. J. Amer. Oil Chem. Soc., 10: 1632-1638.

CVENGROS, J; PAVLOVICOVA, A; GLADISOVA, G and CERNY, J (1999). Rapeseed oil methyl esters with low phosphorus content. Fett/Lipid, 101: 261265.

DSM (2014). MS123-1: 2014 Malaysian Standard Diesel - Specification - Part 1: EURO 2M. Fourth revision. Department of Standards Malaysia, Ministry of Science, Technology and Innovation, Cyberjaya, Malaysia.

GONZALEZ, A (2014). Latin America: despite solid progress in reducing sulfur, several fuel quality challenges remain. Hart Energy Special Report (22 May).

GUZMAN, R C; TANG, H; WADUMESTHRIGE, S; ZHOU, T; GARCIA-PEREZ, M D and NG, K Y S (2010). Quality survey of retail biodiesel blends in Michigan. Fuel, 89: 3662-3667.

ISO (2000). ISO 12937:2000(E) International Standard - Petroleum Products - Determination of Water Coulometric Karl Fischer Titration Method. The International Organization for Standardization, Geneva, Switzerland.

IP (1998). BS EN 116: 1998 Method of Test for Petroleum and its Products Part 309. Diesel and Domestic Heating Fuels - Determination of Cold Filter Plugging Point. The Institute of Petroleum, London, United Kingdom.

MITTELBACH, M and ENZELSBERGER, H (1999). Transesterification of heated rapeseed oil for extending diesel fuel. J. Amer. Oil Chem. Soc., 76: 545550.

TANG, H; ABUNASSER, N; WANG, A; CLARK, B R; WADUMESTHRIGE, $\mathrm{K}$ and ZENG, S (2008). Quality survey of biodiesel blends sold at retail stations. Fuel, 87: 2951-2955.

VORA, K (2013). US: a summary of current fuel quality regulations at the state level. Hart Energy Special Report (29 August). 
WESTBROOK, S and LECREN, R T (2009). Fuels for land and marine diesel engines and for nonaviation gas turbines. Significance of Tests for Petroleum Products (Rand, S J ed.). $8^{\text {th }}$ ed., ASTM International, Massachusetts. p. 33-52.

YUNG, C L; CHOO, Y M; CHENG, S F; MA, A N CHUAH, C H and BASIRON, B (2006). The effect of natural and synthetic antioxidants on the oxidative stability of palm diesel. Fuel, 85: 867-870.

YUNG, C L; LAU, H L N and CHOO, Y M (2013). Physico-chemical properties of biodiesel produced from Jatropha curcas oil and palm oil. J. Oil Palm Res. Vol. 25: 159-164. 